\title{
Comparison of milk protein composition and rennet coagulation properties in native Swedish dairy cow breeds and high-yielding Swedish Red cows
}

\author{
Nina A. Poulsen, ${ }^{* 1}$ Maria Glantz, $†$ Anette K. Rosengaard,* Marie Paulsson, † and Lotte B. Larsen* \\ *Department of Food Science, Science and Technology, Aarhus University, PO Box 50, DK-8830 Tjele, Denmark \\ †Department of Food Technology, Engineering and Nutrition, Lund University, PO Box 124, SE-221 00 Lund, Sweden
}

\begin{abstract}
Recent studies have reported a very high frequency of noncoagulating milk in Swedish Red cows. The underlying factors are not fully understood. In this study, we explored rennet-induced coagulation properties and relative protein profiles in milk from native Swedish Mountain and Swedish Red Polled cows and compared them with a subset of noncoagulating (NC) and well-coagulating (WC) milk samples from modern Swedish Red cows. The native breeds displayed a very low prevalence of NC milk and superior milk coagulation properties compared with Swedish Red cows. The predominant variants in both native breeds were $\alpha_{\mathrm{S}^{-}}$ casein $\left(\alpha_{\mathrm{S} 1}-\mathrm{CN}\right) \mathrm{B}, \beta-\mathrm{CN} \mathrm{A}^{2}$ and $\beta$-lactoglobulin $(\beta-$ $\mathrm{LG}) \mathrm{B}$. For $\kappa-\mathrm{CN}$, the $\mathrm{B}$ variant was predominant in the Swedish Mountain cows, whereas the A variant was the most frequent in the Swedish Red Polled. The native breeds displayed similar protein composition, but varied in content of $\alpha_{S_{1}-} \mathrm{CN}$ with 9 phosphorylated serines (9P) form. Within the Swedish Mountain cows, we observed a strong inverse correlation between the relative concentration of $\kappa-\mathrm{CN}$ and micelle size and a positive correlation between ionic calcium and gel firmness. For comparison, we investigated a subset of $29 \mathrm{NC}$ and $28 \mathrm{WC}$ milk samples, representing the extremes with regard to coagulation properties based on an initial screening of 395 Swedish Red cows. In Swedish Red, NC milk properties were found to be related to higher frequencies of $\beta-\mathrm{CN} \mathrm{A}^{2}, \kappa-\mathrm{CN} \mathrm{E}$ and A variants, as well as $\beta$-LG $\mathrm{B}$, and the predominant composite genotype of $\beta$ - and $\kappa$ - $\mathrm{CN}$ in the $\mathrm{NC}$ group was $\mathrm{A}^{2} \mathrm{~A}^{2} / \mathrm{AA}$. Generally, the $\mathrm{A}^{2} \mathrm{~A}^{2} / \mathrm{AA}$ composite genotype was related to lower relative concentrations of $\kappa$-CN isoforms and higher relative concentrations of $\alpha_{\mathrm{S1}^{-}}, \alpha_{\mathrm{S} 2^{-}}$, and $\beta$-CN. Compared with the group of $\mathrm{WC}$ milk samples, $\mathrm{NC}$ milk contained a higher fraction of $\alpha_{\mathrm{S} 2}-\mathrm{CN}$ and $\alpha$-lactalbumin $(\alpha-\mathrm{LA})$ but a lower fraction
\end{abstract}

Received March 23, 2017.

Accepted August 2, 2017.

${ }^{1}$ Corresponding author: Nina.Poulsen@food.au.dk of $\alpha_{S_{1}-}$ CN 9P. In conclusion, milk from native Swedish breeds has good characteristics for cheese milk, which could be exploited in niche dairy products. In milk from Swedish Mountain cows, levels of ionic calcium seemed to be more important for rennet-induced gel firmness than variation in the relative protein profile. In Swedish Red, lower protein content as well as higher fraction of $\alpha_{\mathrm{S}_{2}}-\mathrm{CN}$ and lower fraction of $\alpha_{\mathrm{S}^{1}} \mathrm{CN} 9 \mathrm{P}$ were related to NC milk. Further, a decrease in the frequency of the composite $\beta-\kappa-C N$ genotype $\mathrm{A}^{2} \mathrm{~A}^{2} / \mathrm{AA}$ through selective breeding could have a positive effect on milk coagulation properties.

Key words: genetic polymorphism, mass spectrometry, liquid chromatography, indigenous cattle

\section{INTRODUCTION}

There is an increasing recognition of the importance of conserving local native dairy breeds, as they might possess unique genetic variation that can affect the milk composition and quality, potentially resulting in distinct milk characteristics that could be exploited in niche dairy products. Further, local breeds embed an awareness of our cultural heritage and often reflect a contrast to modern intensive production systems. In Sweden, Swedish Red Polled and Swedish Mountain cattle are recognized as native breeds. Because of their low effective population sizes, these breeds have, to a large extent, been diluted through crossbreeding with imported high-yielding breeds; the number of living descendants from these breeds is small; 1,000 Swedish Mountain and 450 Swedish Red Polled (Tapio et al., 2006).

Lien et al. (1999) examined 17 native and 5 modern Nordic dairy breeds for common milk protein polymorphisms. Based on these markers, Nordic native breeds could be divided into northern and southern groups, which was later confirmed by Kantanen et al. (2000). Molecular characterizations of 35 northern European breeds suggested 3 distinct phylogenetic groups: Blackand-White type, Baltic Red, and Nordic cattle. Swedish Mountain cattle and Swedish Red Polled belonged to 
the Nordic cattle group; however, sub-structure within the group indicated that Swedish Mountain cattle were more closely related to a group comprising native Finnish breeds, Icelandic cattle, Sided Trönder and Nordland cattle, Fjällnära cattle, and Bohus Poll, than to Swedish Red Polled. Likewise, a grouping of Norwegian Red, Finnish Ayrshire, and Swedish Red documented the common history of these breeds (Tapio et al., 2006). A more detailed cluster analysis conducted by $\mathrm{Li}$ and Kantanen (2010) identified 6 genetic clusters and confirmed the grouping of Swedish Mountain cattle and Swedish Red, whereas Swedish Red Polled had a more admixed ancestry but still exhibited the strongest classification to the group also containing Swedish Mountain cattle.

Proteins in bovine milk can be classified into caseins $\left(\alpha_{\mathrm{S1}^{-}}, \alpha_{\mathrm{S} 2^{-}}, \beta-\right.$, and $\left.\kappa-\mathrm{CN}\right)$ and whey proteins ( $\alpha$-LA and $\beta-\mathrm{LG})$. Examination of genetic variation of the major milk proteins is of interest due to the documented correlation with compositional and technological traits (Wedholm et al., 2006; Hallén et al., 2008; Heck et al., 2009; Poulsen et al., 2013). Protein variant polymorphism previously reported in Swedish cattle breeds documented variation in the number of variants identified as well as their frequencies (Lien et al., 1999). For CSN1S1, encoding $\alpha_{S_{1}-} \mathrm{CN}$, Swedish Mountain cattle had a high frequency of variant C (31\%) compared with Swedish Red Polled cattle (10\%), whereas frequencies of these variants were not reported in Swedish Red. For CSN2, encoding $\beta-\mathrm{CN}$, variants $\mathrm{A}^{1}, \mathrm{~A}^{2}$, and $\mathrm{B}$ were found in similar frequencies in the 2 native breeds compared with Swedish Red, in which only variants $\mathrm{A}^{1}$ and $\mathrm{A}^{2}$ were identified. In CSN3, encoding $\kappa-\mathrm{CN}$, variant $\mathrm{B}$ was found at a very high frequency in Swedish Mountain cattle (71\%) compared with the 2 other breeds. In contrast, CSN3 variant E had a relatively high frequency in Swedish Red Polled (20\%) and in Swedish Red (12\%). For $\beta-\mathrm{LG}$, variants A and B were found in all breeds, but with a predominance of $\beta$-LG B (63-84\%). For Swedish Red, a larger genotyping study (Poulsen et al., 2013) confirmed the reported frequencies by Lien et al. (1999).

Variation in cheese milk quality and high frequencies of noncoagulating (NC) milk samples have been reported in several northern European cattle populations (Ikonen et al., 1999; Tyrisevä et al., 2004; Wedholm et al., 2006; Hallén et al., 2007). In Swedish Red, among the 400 milk samples analyzed, milk from $16 \%$ of the cows did not coagulate (Poulsen et al., 2013) and recently a comparable high frequency was documented in native Red Danish 1970 cows (Poulsen et al., 2017a). The underlying cause of $\mathrm{NC}$ milk is not fully understood, but the phenomenon is partly under genetic influence, with moderate heritability in Swedish Red cows (Gustavsson et al., 2014a). A major QTL explaining 9 to $15 \%$ of the phenotypic variation in different coagulation traits in Swedish Red was identified around the casein gene cluster on chromosome 6 (Gregersen et al., 2015), but genes playing a role in $o$-glycosylation of $\kappa$ - $\mathrm{CN}$ have also been suggested as candidate genes affecting milk coagulation properties (Tyrisevä et al., 2008; Gregersen et al., 2015). Variation in CSN3 have been related to higher relative and absolute content of $\kappa-\mathrm{CN}$ as well as shorter rennet coagulation time and improved curd firmness (Bonfatti et al., 2010a,b). Furthermore, Jensen et al. (2012) found that good coagulation ability was associated with a higher degree of glycosylated $\kappa-\mathrm{CN}$. In addition, variability in the phosphorylated fraction of $\alpha_{\mathrm{S1}^{-}}$and $\alpha_{\mathrm{S}^{-}} \mathrm{CN}$ may play a role (Frederiksen et al., 2011). Gustavsson et al. (2014b) related NC milk to lower ionic and total calcium contents, whereas casein micelle size was more important for variation in gelation properties, when NC milk samples were excluded.

The aim of the present study was to apply liquid chromatography combined with electrospray ionizationmass spectrometry (LC/ESI-MS) to detect genetic variation and relative protein composition in milk from Swedish Red and 2 native Swedish breeds, Swedish Mountain and Swedish Red Polled. Variability in protein composition was associated with rennet-induced milk coagulation properties as well as total and ionic calcium contents and casein micelle size. Further, a subset consisting of $\mathrm{NC}$ and well-coagulating (WC) milk samples from Swedish Red was compared in relation to variant polymorphism of the major milk proteins and variation of posttranslational modifications.

\section{MATERIALS AND METHODS}

\section{Milk Sampling}

Morning milk samples from Swedish Red ( $\mathrm{n}=$ 58) were collected as described by Gustavsson et al. (2014a). Morning milk samples from Swedish Mountain cattle $(\mathrm{n}=23)$ and Swedish Red Polled $(\mathrm{n}=8)$ were collected from southern Sweden (Mjölby and Vellinge, respectively). On the day of sampling, the collected milk samples were aliquoted, skimmed (centrifuged for $30 \mathrm{~min}, 2,000 \times g$ at $4^{\circ} \mathrm{C}$ ), and refrigerated at $4^{\circ} \mathrm{C}$ for up to $6 \mathrm{~h}$ before being subjected to rheological analyses or frozen for later analyses $\left(-20^{\circ} \mathrm{C}\right)$. Individual fresh milk samples were analyzed for SCC using flow cytometry (Fossomatic 5000, Foss Analytical, Hillerød, Denmark) and overall milk composition (contents of total protein, fat and lactose) using infrared spectroscopy (MilkoScan FT2, Foss Analytical) at a certified 
dairy analysis laboratory (Eurofins Steins Laboratory, Jönköping, Sweden).

\section{Protein Profiling Using LC/ESI-MS}

The LC/ESI-MS analysis was based on previous studies (Bobe et al., 1998; Bonfatti et al., 2008) but modified according to Jensen et al. (2012). The elution gradient started at 5\% solvent $\mathrm{B}$ [acetonitrile $(\mathrm{ACN})$ :water:trifluoroacetic acid (TFA), 1,000:1:1 vol/ $\mathrm{vol} / \mathrm{vol}]$ mixed in solvent A (ACN:water:TFA, 1:1,000:1 $\mathrm{vol} / \mathrm{vol} / \mathrm{vol}$ ) and subsequently increased to $32 \%$ solvent B for $10 \mathrm{~min}$, followed by an increase to $50 \%$ solvent B for $55 \mathrm{~min}$, and finally to $50 \%$ solvent B for $5 \mathrm{~min}$. Samples were analyzed in duplicate using a HPLC 1100 system (Agilent Technologies, Santa Clara, CA) with a Jupiter C4 column $(250 \times 2 \mathrm{~mm}, 5 \mu \mathrm{m}$ particle size, $300 \AA$ pores; Phenomenex, Torrance, CA) operated at $40^{\circ} \mathrm{C}$ and a G1315A diode array detector with UV detection at $214 \mathrm{~nm}$, coupled to a mass selective detector for identification. Relative protein concentrations were quantified for all caseins $\left(\alpha_{S_{1}}-\mathrm{CN}, \alpha_{S_{2}}-\mathrm{CN}, \beta-\mathrm{CN}\right.$, and $\kappa-\mathrm{CN})$ and major whey proteins $(\alpha-\mathrm{LA}$ and $\beta-\mathrm{LG})$ as the integrated peak area of a given protein to total integrated protein peak area (sum of $\alpha_{\mathrm{S}^{-}} \mathrm{CN}, \alpha_{\mathrm{S} 2}-\mathrm{CN}$, $\beta-\mathrm{CN}, \kappa-\mathrm{CN}, \alpha-\mathrm{LA}$, and $\beta-\mathrm{LG})$. Further, specific posttranslational modifications were identified and quantified, including glycosylated $\kappa-\mathrm{CN}$ ( $\boldsymbol{\kappa}-\mathbf{C N} \mathbf{G})$, unglycosylated $\kappa-\mathrm{CN}(\boldsymbol{\kappa}-\mathbf{C N} \mathbf{U G}), \alpha_{\mathrm{S}_{1}}-\mathrm{CN} 8 \mathrm{P}$, and $\alpha_{\mathrm{S}_{1}} \mathrm{CN}$ 9P (where $\mathrm{P}$ indicates the number of phosphorylated groups attached). Furthermore, the glycosylation degree (GD) of $\kappa-\mathrm{CN}$ was defined as $\kappa-\mathrm{CN} \mathrm{G} /$ total $\kappa-\mathrm{CN}$, and the phosphorylation degree (PD) of $\alpha_{\mathrm{S}_{1}-\mathrm{CN}}$ was defined as $\alpha_{\mathrm{S}^{-}} \mathrm{CN} 8 \mathrm{P} /$ total $\alpha_{\mathrm{S}_{1}}-\mathrm{CN}$.

\section{Rheological Analyses for Determination of Milk Coagulation Properties}

An aliquot of $30 \mathrm{~mL}$ of skim milk from each cow was preserved with a bronopol solution $(2 \mu \mathrm{L} / \mathrm{mL}, 17 \%$ wt/vol, Sigma-Aldrich Logistik GmbH, Schnelldorf, Germany) according to Hallén et al. (2007) on the day of sampling. Low-amplitude oscillation measurements were performed on chymosin-induced skim milk gels using a vane/cup setup in a Stresstech rheometer (ReoLogica Instruments AB, Lund, Sweden) according to the method of Glantz et al. (2011). In short, skim milk samples were kept at $32^{\circ} \mathrm{C}$ for 30 min, chymosin was added $(0.44 \mathrm{~mL} / \mathrm{L}$ of milk, Chy-Max Plus, 205 international milk clotting units (IMCU)/L, Chr. Hansen A/S, Hørsholm, Denmark). The solution was gently stirred and added to the rheometer cup. Measurements were performed at $32^{\circ} \mathrm{C}$ for $40 \mathrm{~min}$ with controlled strain at 0.01 and $1 \mathrm{~Hz}$ followed by a stress sweep for $5 \mathrm{~min}$. The addition of chymosin corresponded to time 0 . Gel strength $\left(\mathbf{G}^{\prime}\right)$ was recorded during the measurement where $\mathrm{G}^{\prime}$ was defined as the elastic or storage modulus after $30 \mathrm{~min}\left(\mathbf{G}^{\prime} \mathbf{3 0}\right)$ and $40 \mathrm{~min}\left(\mathbf{G}^{\prime} \mathbf{4 0}\right)$ of coagulation, as described in Glantz et al. (2011). The moment when $\mathrm{G}^{\prime}$ starts to increase continuously was defined as rennet coagulation time (RCT). The stress sweep was performed by increasing the shear stress in 100 intervals from 0.1 to $300 \mathrm{~Pa}$ as described by Glantz et al. (2011), and yield stress (YS), a measure of large deformation properties, was defined as the shear stress when the viscosity reached $90 \%$ of the maximum recorded viscosity in the stress sweep. Previously reported milk coagulation properties in approximately 400 Swedish Red milk samples (Gustavsson et al., 2014a) were used to define a subset representing samples with the most extreme milk coagulation properties. The subset consisted of 29 NC milk samples $\left(\mathrm{RCT}=40 \mathrm{~min}, \mathrm{G}^{\prime} 40=0, \mathrm{YS}=0\right)$ and $28 \mathrm{WC}$ milk samples (RCT $<9.8 \mathrm{~min}, \mathrm{G}^{\prime} 40>100.1$ $\mathrm{Pa}$, and $\mathrm{YS}>17.8 \mathrm{~Pa}$ ), which was used for protein profiling. All rheological analyses were conducted on skim milk without any $\mathrm{pH}$ adjustment.

\section{Measurements of Ionic and Total Calcium}

Measurements of ionic calcium (free $\mathrm{Ca}^{2+}$ ) were performed on fresh milk at $32^{\circ} \mathrm{C}$ using a calcium electrode (Orion 97-20 Ionplus Calcium Electrode; Thermo Electron Corp., Beverly, MA) as previously described (Glantz et al., 2011). Total calcium measurement was performed using an automated potentiometric titrator (Metrohm 862, Metrohm, Herisau, Switzerland), coupled with a double-junction $\mathrm{Ag} / \mathrm{AgCl}$ reference electrode (LL ISE Reference 6.0750.100, Metrohm) and a $\mathrm{Ca}^{2+}$ ion-selective electrode (scION Ca Tip, 6.0509.000, Metrohm). Titration was performed using a $0.01 \mathrm{M}$ EGTA-0.1 N KOH solution. Briefly, for total calcium, frozen milk samples were thawed at room temperature, and aliquots of $20 \mathrm{~mL}$ were acidified to $\mathrm{pH} 4.3$ with $0.5 \mathrm{M} \mathrm{HCl}$, followed by centrifugation at $3,500 \times g$ for $5 \mathrm{~min}$. For each sample, about $2 \mathrm{~g}$ of supernatant was transferred to titration tubes and weighed. Then, 10 $\mathrm{mL}$ of $0.1 M$ borax buffer $\left(\mathrm{Na}_{2} \mathrm{~B}_{4} \mathrm{O}_{7} \cdot 10 \mathrm{H}_{2} \mathrm{O}\right.$ in milliQ water; Millipore Corp., Bedford, MA) and $80 \mathrm{~mL}$ of milliQ water were added into the tubes. Measurement of total calcium was performed in duplicates.

\section{Casein Micelle Size}

Casein micelle size distributions were measured by laser light scattering (Mastersizer 2000 with a Hydro 2000 SM sampling unit; Malvern Instruments, Malvern, 
UK). Before measurements, fresh milk samples were set to room temperature. The sampling unit was filled with room tempered pure water, which was prepared with a milli-Q system (Millipore Corp.), the sampler unit pump was set at $1,500 \mathrm{rpm}$, milk was added until $8 \%$ obscuration was obtained, and the measurement was started. This procedure was repeated twice for each sample. Using the software supplied with the instrument (Malvern application, v 5.60, Malvern Instruments), the average volume-weighted diameter $(\mathrm{D}[4,3])$ was determined in each milk sample. The refractive index for casein micelles was set to 1.51. To avoid interference of remaining fat, only particles with diameters between 0.02 and $0.83 \mu \mathrm{m}$ were included when estimating $\mathrm{D}[4,3]$ of the casein micelles.

\section{Data Analysis}

One-way ANOVA was used to compare means between coagulation groups and between breeds. If more than 2 groups were compared, pairwise comparison tests were done using Tukey's pairwise post hoc test. As the casein loci are tightly linked on chromosome 6 , we examined the effects of $\beta-\kappa-\mathrm{CN}$ composite genotype on detailed milk compositional traits. For Swedish Red, $\beta-\kappa-\mathrm{CN}$ composite genotypes that were present in more than 2 animals were included in the model, resulting in 7 different $\beta-\kappa-C N$ composite genotypes. The lowfrequency $\beta-\kappa-\mathrm{CN}$ composite genotypes present in only 1 or 2 animals were combined into one group $(\mathrm{n}=8)$ and added to the model in line with the other $\beta-\kappa-C N$ composite genotypes. For Swedish Mountain cattle, 6 different $\beta-\kappa-C N$ composite genotypes were included together with a group containing those $\beta-\kappa-\mathrm{CN}$ composite genotypes being present in only one animal. Briefly, as outlined in Poulsen et al. (2013), the individual composite genotype was fitted as a covariate in the model by using a dummy vector with 0 or 1 , where 0 indicates that the animal does not have the composite genotype and 1 indicates that the animal has the composite genotype. This will give the same result as fitting the composite genotype as a fixed effect with $n$ levels, but allowing a choice of reference genotype. In Swedish Red, the most common genotype of the $\mathrm{NC}$ group $\left(\mathrm{A}^{2} \mathrm{~A}^{2} / \mathrm{AA}\right)$ was used as the reference $\beta-\kappa-\mathrm{CN}$ composite genotype, and $\mathrm{A}^{2} \mathrm{~A}^{2} / \mathrm{AB}$ was used as reference composite genotype in Swedish Mountain cattle. Due to the small sample size of Swedish Red Polled, the effect of $\beta-\kappa-C N$ composite genotype was not tested. Likewise, Pearson correlations between the studied variables and their significances $(\alpha$ $=0.01$ ) were only studied in Swedish Mountain cattle. These were generated using the R-package corrplot. All tests were performed in $\mathrm{R}$ (version 2.15.1; http://www .r-project.org).

\section{RESULTS}

\section{Protein Variant Distribution as Identified by LC/ESI-MS}

Frequencies of $\alpha_{\mathrm{S} 1}-\mathrm{CN}, \beta-\mathrm{CN}, \kappa-\mathrm{CN}$, and $\beta-\mathrm{LG}$ variants for the 2 groups of coagulation extremes in Swedish Red and the 2 native breeds are given in Table 1. In total, 3 protein variants were identified for $\kappa-\mathrm{CN}$ $(\mathrm{A}, \mathrm{B}, \mathrm{E}), 4$ variants for $\beta-\mathrm{CN}\left(\mathrm{A}^{1}, \mathrm{~A}^{2}, \mathrm{~B}, \mathrm{~F}\right), 2$ variants for $\alpha_{S_{1}} \mathrm{CN}(\mathrm{B}, \mathrm{C})$, and 2 variants for $\beta-\mathrm{LG}$ (A, B) using LC/ESI-MS. In the native breeds, $\alpha_{\mathrm{S1}}-\mathrm{CN}$ variants $\mathrm{B}$ and $\mathrm{C}$ were identified in both breeds, but variant $\mathrm{C}$ was present at a higher frequency in Swedish Mountain cows (15\%) than in Swedish Red Polled $(6 \%)$. For $\beta$-CN, variants $\mathrm{A}^{1}, \mathrm{~A}^{2}$, and $\mathrm{B}$ were all found in Swedish Mountain cattle, whereas only variants $\mathrm{A}^{1}$ and $\mathrm{A}^{2}$ were identified in Swedish Red Polled. In both breeds, $\beta-\mathrm{CN} \mathrm{A}^{2}$ was the predominant variant.

Table 1. Frequencies (\%) of protein variants of $\alpha_{\mathrm{S}_{1}} \mathrm{CN}, \beta-\mathrm{CN}, \kappa-\mathrm{CN}$, and $\beta$-LG identified in milk from individual Swedish Mountain (SM), Swedish Red Polled (SRP), and Swedish Red (SR) ${ }^{1}$ cows identified using liquid chromatography/electrospray ionization-MS analysis

\begin{tabular}{|c|c|c|c|c|c|}
\hline Protein & Variant & $\mathrm{SM}(\mathrm{n}=23)$ & $\operatorname{SRP}(\mathrm{n}=8)$ & $\mathrm{SR} \mathrm{NC}(\mathrm{n}=29)$ & $\mathrm{SR} \mathrm{WC}(\mathrm{n}=28)$ \\
\hline \multirow[t]{2}{*}{$\alpha_{\mathrm{S}-\mathrm{CN}}$} & B & 84.8 & 93.8 & 100 & 98.2 \\
\hline & $\mathrm{C}$ & 15.2 & 6.3 & - & 1.8 \\
\hline \multirow[t]{4}{*}{$\beta-\mathrm{CN}$} & $\mathrm{A}^{1}$ & 30.4 & 25.0 & 27.6 & 53.6 \\
\hline & $\mathrm{A}^{2}$ & 56.5 & 75.0 & 70.7 & 41.1 \\
\hline & $\mathrm{B}$ & 13.0 & - & - & 5.4 \\
\hline & $\mathrm{F}$ & - & - & 1.7 & - \\
\hline \multirow[t]{3}{*}{$\kappa-\mathrm{CN}$} & $\mathrm{A}$ & 30.4 & 62.5 & 65.5 & 60.7 \\
\hline & B & 69.6 & 18.8 & 17.2 & 25.0 \\
\hline & $\mathrm{E}$ & - & 18.8 & 17.2 & 14.3 \\
\hline \multirow[t]{2}{*}{$\beta-\mathrm{LG}$} & $\mathrm{A}$ & 28.3 & 18.8 & 34.5 & 48.2 \\
\hline & B & 71.7 & 81.3 & 65.5 & 51.8 \\
\hline
\end{tabular}

${ }^{1} \mathrm{NC}=$ noncoagulating; $\mathrm{WC}=$ well-coagulating milk samples from Swedish Red. 
For $\kappa-\mathrm{CN}$, variant $\mathrm{B}$ was the predominant variant in Swedish Mountain cows, whereas $\kappa$-CN A was most frequent in Swedish Red Polled. In Swedish Mountain cows, $\kappa-\mathrm{CN} \mathrm{E}$ was not identified, whereas $\kappa-\mathrm{CN} \mathrm{E}$ had a relatively high frequency in Swedish Red Polled. For both breeds, $\beta$-LG B was the most common variant, but $\beta$-LG A was also present at relatively high frequencies.

In Swedish Red, comparison of variant frequencies in the NC and WC groups revealed that higher frequencies of $\beta-\mathrm{CN} \mathrm{A}{ }^{2}, \kappa-C N A$ and $\mathrm{E}$, and $\beta-\mathrm{LG} \mathrm{B}$ were mainly associated with $\mathrm{NC}$ samples. Further, $\beta-\mathrm{CN}$ F was found exclusively in one $\mathrm{NC}$ sample, whereas $\beta-\mathrm{CN}$ $\mathrm{B}$ and $\alpha_{\mathrm{S} 1}-\mathrm{CN} \mathrm{C}$ were only found in $\mathrm{WC}$ samples. Thus, Swedish Red WC milk was associated with higher frequencies of $\beta-\mathrm{CN} \mathrm{A}^{1}$ and $\beta$-CN B together with $\kappa-\mathrm{CN} \mathrm{B}$ and $\beta$-LG A.

\section{Milk Coagulation Properties and Relative Protein Composition in Swedish Red Cows}

Table 2 shows that Swedish Red cows producing NC milk were earlier in lactation than cows producing WC milk $(P=0.040)$ and had significantly lower parity $(P$ $=0.006)$. Further, NC milk was also associated with significantly lower protein content $(P=0.011)$, whereas no differences were observed in relation to SCC and $\mathrm{pH}$.
Somatic cell count was generally low in both groups and little variation in $\mathrm{pH}$ was observed (Table 2).

Relative protein composition of the major proteins $\left(\alpha_{\mathrm{S1}^{-}}, \alpha_{\mathrm{S} 2^{-}}, \beta-, \kappa-\mathrm{CN}, \alpha-\mathrm{LA}\right.$, and $\left.\beta-\mathrm{LG}\right)$ was quantified from integration of the UV signal from the HPLC elution profile, including isoform variation for $\alpha_{\mathrm{S1}^{-}} \mathrm{CN}$ and $\kappa-\mathrm{CN}$ and their related GD and PD. The results showed that NC milk samples had significantly higher relative contents of $\alpha_{\mathrm{S}^{2}} \mathrm{CN}(P=0.0004)$ and $\alpha$-LA $(P=0.010)$ and lower relative content of $\alpha_{\mathrm{S} 1}-\mathrm{CN} 9 \mathrm{P}(P=0.034)$ compared with WC samples (Table 2).

\section{Effect of Composite $\beta-\kappa-C N$ Genotypes in Swedish Red Milk}

For Swedish Red, composite $\beta$ - $\kappa-C N$ genotypes had a significant effect on the relative concentrations of major proteins and their isoforms (Tables 3 and 4). Genotype $\mathrm{A}^{2} \mathrm{~A}^{2} / \mathrm{AA}$, which was the most common genotype in $\mathrm{NC}$ milk, was used as the reference genotype and represented significantly lower relative concentration of $\kappa$-CN compared with all other composite genotypes except $\mathrm{A}^{1} \mathrm{~A}^{1} / \mathrm{AE}$ and $\mathrm{A}^{2} \mathrm{~A}^{2} / \mathrm{AB}$. This was further reflected in a lower concentration of, particularly, $\kappa-\mathrm{CN} G$ in $\mathrm{A}^{2} \mathrm{~A}^{2} / \mathrm{AA}$ compared with most genotypes, whereas only $\mathrm{A}^{1} \mathrm{~A}^{2} / \mathrm{AE}(P=0.011)$ had significantly higher relative concentration of $\kappa$-CN UG compared with $\mathrm{A}^{2} \mathrm{~A}^{2} / \mathrm{AA}$.

Table 2. Descriptive statistics of milk and relative protein compositional traits of noncoagulating $(\mathrm{NC} ; \mathrm{n}=29)$ and well-coagulating $($ WC; $\mathrm{n}=$ 28) milk samples from Swedish Red (mean, SD, minimum, and maximum)

\begin{tabular}{|c|c|c|c|c|c|c|c|c|c|}
\hline \multirow[b]{2}{*}{ Trait $^{1}$} & \multicolumn{4}{|c|}{ Noncoagulating samples } & \multicolumn{4}{|c|}{ Well-coagulating samples } & \multirow[b]{2}{*}{$\mathrm{NC}$ vs. $\mathrm{WC}^{2}$} \\
\hline & Mean & $\mathrm{SD}$ & Minimum & Maximum & Mean & $\mathrm{SD}$ & Minimum & Maximum & \\
\hline DIM & 198 & 68 & 70 & 346 & 241 & 86 & 73 & 377 & $*$ \\
\hline Parity & 1.5 & 0.7 & 1.0 & 3.0 & 2.1 & 0.7 & 1.0 & 3.0 & $* *$ \\
\hline Protein $(\mathrm{g} / 100 \mathrm{~g})$ & 3.7 & 0.3 & 3.1 & 4.5 & 4.0 & 0.4 & 3.3 & 4.8 & $*$ \\
\hline $\mathrm{SCC}\left(\times 10^{3}\right.$ cells $\left./ \mathrm{mL}\right)$ & 57 & 51 & 9 & 166 & 61 & 62 & 7 & 249 & NS \\
\hline $\mathrm{pH}$ & 6.6 & 0.1 & 6.5 & 6.8 & 6.7 & 0.1 & 6.6 & 6.8 & NS \\
\hline $\mathrm{RCT}(\min )$ & $>40$ & - & - & - & 8.4 & 2.5 & 5.2 & 15.7 & - \\
\hline $\mathrm{G}^{\prime} 30(\mathrm{~Pa})$ & 0 & - & - & - & 138.4 & 56.9 & 44.3 & 276.1 & - \\
\hline $\mathrm{G}^{\prime} 40(\mathrm{~Pa})$ & 0 & - & - & - & 180.4 & 58.1 & 104.1 & 312.7 & - \\
\hline Yield stress $(\mathrm{Pa})$ & 0 & - & - & - & 24.4 & 4.0 & 18.9 & 33.4 & - \\
\hline$\alpha_{\mathrm{S} 1^{-}} \mathrm{CN}(\%)$ & 31.8 & 2.0 & 27.9 & 36.5 & 32.5 & 1.7 & 29.7 & 35.9 & NS \\
\hline$\alpha_{\mathrm{S} 1}-\mathrm{CN} 8 \mathrm{P}(\%)$ & 23.4 & 1.9 & 20.1 & 26.3 & 23.4 & 1.4 & 19.8 & 26.0 & NS \\
\hline$\alpha_{\mathrm{S} 1}-\mathrm{CN} 9 \mathrm{P}(\%)$ & 8.4 & 1.3 & 6.4 & 11.3 & 9.2 & 1.3 & 6.8 & 11.4 & $*$ \\
\hline$\alpha_{\mathrm{S} 1}-\mathrm{CN} 8 \mathrm{P} / \alpha_{\mathrm{S} 1}-\mathrm{CN}(\%)$ & 73.5 & 3.8 & 64.9 & 80.3 & 71.8 & 3.3 & 64.4 & 78.4 & NS \\
\hline$\alpha_{\mathrm{S} 2^{-}} \mathrm{CN}(\%)$ & 7.8 & 1.5 & 5.8 & 11.7 & 6.6 & 0.8 & 4.9 & 8.3 & $* * *$ \\
\hline$\beta-\mathrm{CN}(\%)$ & 41.1 & 1.6 & 37.8 & 43.9 & 41.9 & 2.2 & 35.9 & 45.3 & NS \\
\hline$\kappa-\mathrm{CN}(\%)$ & 7.6 & 1.7 & 5.3 & 12.8 & 8.2 & 1.2 & 6.0 & 11.3 & NS \\
\hline$\kappa-\mathrm{CN}$ G $(\%)$ & 2.2 & 0.8 & 1.0 & 3.6 & 2.5 & 1.1 & 1.3 & 4.8 & NS \\
\hline$\kappa-\mathrm{CN} \mathrm{UG}(\%)$ & 5.4 & 1.5 & 3.0 & 10.8 & 5.7 & 1.0 & 3.9 & 7.8 & NS \\
\hline$\kappa-\mathrm{CN}$ G/к-CN (\%) & 29.8 & 9.9 & 14.6 & 48.6 & 30.0 & 10.3 & 16.3 & 51.2 & NS \\
\hline$\alpha-\mathrm{LA}(\%)$ & 3.9 & 0.7 & 2.4 & 5.3 & 3.4 & 0.7 & 2.2 & 4.6 & $* *$ \\
\hline$\beta-\mathrm{LG}(\%)$ & 7.9 & 1.8 & 3.2 & 10.9 & 7.5 & 1.9 & 3.2 & 12.3 & NS \\
\hline
\end{tabular}

${ }^{1} \mathrm{RCT}=$ rennet coagulation time, $\mathrm{G}^{\prime} 30$ and $\mathrm{G}^{\prime} 40=$ storage modulus after 30 and 40 min, respectively; $8 \mathrm{P}$ and $9 \mathrm{P}=$ degree of phosphorylation; $\kappa-\mathrm{CN} \mathrm{G}$ and $\kappa-\mathrm{CN} \mathrm{UG}=$ glycosylated and unglycosylated $\kappa-\mathrm{CN}$, respectively.

${ }^{2}$ Effect of coagulation group on milk compositional traits: ${ }^{*} P<0.05$, ${ }^{* *} P<0.01,{ }^{*} * *<<0.001$. 
Table 3. Estimated differences $( \pm \mathrm{SE})$ for relative concentrations of $\kappa-\mathrm{CN}$, glycosylated $\kappa-\mathrm{CN}(\kappa-\mathrm{CN} \mathrm{G})$, unglycosylated $\kappa-\mathrm{CN}(\kappa-\mathrm{CN} \mathrm{UG})$, and $\kappa$-CN glycosylation degree $(\kappa-\mathrm{CN}$ GD) comparing $\beta-\kappa-\mathrm{CN}$ composite genotypes with the reference composite genotype, $\mathrm{A}^{2} \mathrm{~A}^{2} / \mathrm{AA}$, in Swedish Red cows

\begin{tabular}{|c|c|c|c|c|}
\hline$\beta-\kappa-C N$ genotype ${ }^{1}$ & $\kappa-\mathrm{CN}(\%)$ & $\kappa-\mathrm{CN}$ G $(\%)$ & к-CN UG (\%) & $\kappa-\mathrm{CN}$ GD $(\%)$ \\
\hline$\overline{\mathrm{A}^{2} \mathrm{~A}^{2} / \mathrm{AA}(\mathrm{n}=8 / 1)}$ & 0 & 0 & 0 & 0 \\
\hline $\mathrm{A}^{1} \mathrm{~A}^{1^{\prime}} / \mathrm{AE}(\mathrm{n}=0 / 4)^{\prime}$ & $0.98 \pm 0.73$ & $0.56 \pm 0.51$ & $0.42 \pm 0.72$ & $4.54 \pm 5.60$ \\
\hline $\mathrm{A}^{1} \mathrm{~A}^{2} / \mathrm{AB}(\mathrm{n}=3 / 3)$ & $1.95 \pm 0.64^{* *}$ & $1.22 \pm 0.44^{* *}$ & $0.72 \pm 0.63$ & $10.56 \pm 4.91^{*}$ \\
\hline $\mathrm{A}^{1} \mathrm{~A}^{2} / \mathrm{AE}(\mathrm{n}=6 / 1)$ & $2.24 \pm 0.61$ *** & $0.66 \pm 0.42$ & $1.59 \pm 0.60^{*}$ & $2.00 \pm 4.70$ \\
\hline $\mathrm{A}^{1} \mathrm{~A}^{2} / \mathrm{BE}(\mathrm{n}=3 / 3)$ & $2.31 \pm 0.64^{* * *}$ & $1.05 \pm 0.44^{*}$ & $1.26 \pm 0.63 \dagger$ & $5.10 \pm 4.91$ \\
\hline $\mathrm{A}^{1} \mathrm{~A}^{2} / \mathrm{AA}(\mathrm{n}=3 / 9)$ & $1.56 \pm 0.54^{* *}$ & $0.99 \pm 0.37^{*}$ & $0.57 \pm 0.53$ & $7.78 \pm 4.11 \dagger$ \\
\hline $\mathrm{A}^{2} \mathrm{~A}^{2^{2}} / \mathrm{AB}(\mathrm{n}=4 / 1)$ & $0.58 \pm 0.68$ & $1.26 \pm 0.47^{* *}$ & $-0.68 \pm 0.66$ & $17.28 \pm 5.20^{* *}$ \\
\hline Other $^{2}(\mathrm{n}=2 / 6)$ & $2.60 \pm 0.59^{* * *}$ & $1.56 \pm 0.41^{* * *}$ & $1.04 \pm 0.58 \dagger$ & $10.15 \pm 4.53^{*}$ \\
\hline Mean & $6.34 \pm 0.41$ & $1.46 \pm 0.28$ & $4.88 \pm 0.40$ & $23.10 \pm 3.11$ \\
\hline
\end{tabular}

${ }^{1}$ All cows were homozygous for $\alpha_{\mathrm{S}_{1}} \mathrm{CN}$ variant $\mathrm{BB}$ except one $\mathrm{A}^{1} \mathrm{~A}^{2} / \mathrm{AB} \mathrm{WC}$ sample, which was $\alpha_{\mathrm{S}^{-}} \mathrm{CN} \mathrm{BC}$. Numbers in parentheses refer to number of milk samples in the noncoagulating (NC) and well-coagulating (WC) groups, respectively

${ }^{2}$ Other refers to composite $\beta$ - $\kappa$-CN genotypes only found in 1 or 2 cows in Swedish Red. $\dagger P<0.1,{ }^{*} P<0.05,{ }^{* *} P<0.01,{ }^{* * *} P<0.001$.

Thus, GD was only significantly higher in $\mathrm{A}^{1} \mathrm{~A}^{2} / \mathrm{AB}(P$ $=0.037), \mathrm{A}^{2} \mathrm{~A}^{2} / \mathrm{AB}(P=0.002)$, and in the group of other low-abundance composite genotypes $(P=0.030)$ compared with $\mathrm{A}^{2} \mathrm{~A}^{2} / \mathrm{AA}$ (Table 3 ).

For $\alpha_{\mathrm{S}_{2}} \mathrm{CN}, \mathrm{A}^{1} \mathrm{~A}^{1} / \mathrm{AE}(P=0.035), \mathrm{A}^{1} \mathrm{~A}^{2} / \mathrm{AB}(P=$ $0.020)$, and $\mathrm{A}^{1} \mathrm{~A}^{2} / \mathrm{BE}(P=0.003)$ had significantly lower $\alpha_{\mathrm{S}^{2}} \mathrm{CN}$ content compared with the reference genotype (Table 4). Both $\mathrm{A}^{1} \mathrm{~A}^{2} / \mathrm{AB}$, and $\mathrm{A}^{1} \mathrm{~A}^{2} / \mathrm{BE}$ also had significantly lower relative concentration of $\alpha_{S 1}$ CN $8 \mathrm{P}(P=0.004$ and 0.030 , respectively $)$ and total $\alpha_{\mathrm{S}_{1}} \mathrm{CN}(P=0.012$ and 0.003 , respectively), and significantly higher relative concentration of $\beta-\mathrm{CN}(P$ $=0.029$ and 0.003 , respectively) compared with $\mathrm{A}^{2} \mathrm{~A}^{2} /$ AA. Genotype $\mathrm{A}^{1} \mathrm{~A}^{2} / \mathrm{AA}$ displayed the same pattern for $\alpha_{\mathrm{S}_{1}} \mathrm{CN} 8 \mathrm{P}(P=0.008)$, total $\alpha_{\mathrm{S1}^{-}} \mathrm{CN}(P=0.008)$, and $\beta$-CN $(P=0.009)$, whereas $\mathrm{A}^{1} \mathrm{~A}^{2} / \mathrm{AE}$ had significantly higher relative concentration of $\alpha_{\mathrm{S} 1}-\mathrm{CN} 8 \mathrm{P}(P=0.004)$ and total $\alpha_{\mathrm{S}_{1}} \mathrm{CN}(P=0.014)$. Variability in $\alpha_{\mathrm{S} 1}-\mathrm{CN}$ $9 \mathrm{P}, \alpha_{\mathrm{S} 1}-\mathrm{CN} \mathrm{PD}, \beta-\mathrm{LG}$, and $\alpha-\mathrm{LA}$ were not significantly affected by composite genotypes in Swedish Red.

\section{Effect of $\beta-L G$ Variants on Relative Concentration of $\beta-L G$}

Variation in $\beta$-LG was shown to affect the relative concentration of $\beta$-LG similarly in all breeds, with AA genotypes having the highest relative concentration, $\mathrm{BB}$ genotypes the lowest, and $\mathrm{AB}$ genotypes intermediate levels (Figure 1). In Swedish Red and Swedish Mountain cows, AA $(P=0.0007$ and $P=0.0189$, respectively) and $\mathrm{AB}(P=0.0385$ and $P=0.0007$, respectively) genotypes had significantly higher relative concentration of $\beta-\mathrm{LG}$ compared with $\mathrm{BB}$ genotypes, whereas the $\beta$-LG concentration between $\mathrm{AA}$ and $\mathrm{AB}$ genotypes did not differ. In Swedish Red Polled cows, only $\mathrm{AB}$ and $\mathrm{BB}$ genotypes were identified and the same overall pattern was observed, even though it was not significant.

Apart from affecting $\beta$-LG variability, $\beta$-LG genotypes significantly affected the relative concentration of $\alpha_{\mathrm{S} 1}-\mathrm{CN} 8 \mathrm{P}$ in Swedish Red, with AA and AB genotypes

Table 4. Estimated differences $( \pm \mathrm{SE})$ for relative $\alpha_{\mathrm{S1}^{-}} \mathrm{CN}, \alpha_{\mathrm{S} 2}-\mathrm{CN}$, and $\beta$-CN comparing $\beta$ - $\kappa$-CN composite genotypes with the common composite genotype, $\mathrm{A}^{2} \mathrm{~A}^{2} / \mathrm{AA}$, in Swedish Red cows

\begin{tabular}{|c|c|c|c|c|}
\hline$\beta-\kappa-C N$ genotype ${ }^{1}$ & $\alpha_{\mathrm{S}-}-\mathrm{CN} 8 \mathrm{P}(\%)$ & $\alpha_{S 1}-\mathrm{CN}(\%)$ & $\alpha_{\mathrm{S}^{2}}-\mathrm{CN}(\%)$ & $\beta-\mathrm{CN}(\%)$ \\
\hline$\overline{\mathrm{A}^{2} \mathrm{~A}^{2} / \mathrm{AA}(\mathrm{n}=8 / 1)}$ & 0 & 0 & 0 & 0 \\
\hline $\mathrm{A}^{1} \mathrm{~A}^{1} / \mathrm{AE}(\mathrm{n}=0 / 4)$ & $-0.90 \pm 0.91$ & $-0.27 \pm 1.02$ & $-1.61 \pm 0.74^{*}$ & $1.42 \pm 1.09$ \\
\hline $\mathrm{A}^{1} \mathrm{~A}^{2} / / \mathrm{AB}(\mathrm{n}=3 / 3)$ & $-2.42 \pm 0.79^{* *}$ & $-2.34 \pm 0.89 *$ & $-1.57 \pm 0.65^{*}$ & $2.14 \pm 0.95^{*}$ \\
\hline $\mathrm{A}^{1} \mathrm{~A}^{2} / \mathrm{AE}(\mathrm{n}=6 / 1)$ & $-2.31 \pm 0.76^{* *}$ & $-2.19 \pm 0.85^{*}$ & $-0.40 \pm 0.62$ & $0.82 \pm 0.91$ \\
\hline $\mathrm{A}^{1} \mathrm{~A}^{2} / \mathrm{BE}(\mathrm{n}=3 / 3)$ & $-1.78 \pm 0.79^{*}$ & $-2.80 \pm 0.89^{* *}$ & $-2.07 \pm 0.65^{* *}$ & $2.98 \pm 0.95^{* *}$ \\
\hline $\mathrm{A}^{1} \mathrm{~A}^{2} / \mathrm{AA}(\mathrm{n}=3 / 9)$ & $-1.85 \pm 0.67^{* *}$ & $-2.07 \pm 0.75^{* *}$ & $-0.69 \pm 0.55$ & $2.18 \pm 0.80^{* *}$ \\
\hline $\mathrm{A}^{2} \mathrm{~A}^{2} / \mathrm{AB}(\mathrm{n}=4 / 1)$ & $-1.05 \pm 0.84$ & $-1.52 \pm 0.94$ & $-0.40 \pm 0.69$ & $0.13 \pm 1.01$ \\
\hline $\operatorname{Other}^{2}(\mathrm{n}=2 / 6)$ & $-1.24 \pm 0.74 \dagger$ & $-0.69 \pm 0.82$ & $-1.20 \pm 0.60 \dagger$ & $0.60 \pm 0.88$ \\
\hline Mean & $24.82 \pm 0.50$ & $33.68 \pm 0.57$ & $8.07 \pm 0.41$ & $40.16 \pm 0.60$ \\
\hline
\end{tabular}

${ }^{1}$ All cows were homozygous for $\alpha_{\mathrm{S1}^{-}} \mathrm{CN}$ variant $\mathrm{BB}$ except one $\mathrm{A}^{1} \mathrm{~A}^{2} / \mathrm{AB} \mathrm{WC}$ sample, which was $\alpha_{\mathrm{S} 1}-\mathrm{CN} \mathrm{BC}$. Numbers in parentheses refer to number of milk samples in the noncoagulating and well-coagulating (WC) groups, respectively.

${ }^{2}$ Other refers to composite $\beta$ - $-\mathrm{CN}$ genotypes only found in 1 or 2 cows in Swedish Red.

$\dagger P<0.1,{ }^{*} P<0.05,{ }^{* *} P<0.01$. 
having significantly lower relative concentration of $\alpha_{\mathrm{S} 1}-\mathrm{CN} 8 \mathrm{P}$ compared with $\mathrm{BB}$ genotypes $(P=0.0143$ and $P=0.0319$, respectively) and the relative concentration of $\alpha-\mathrm{LA}$, with $\mathrm{AA}$ and $\mathrm{AB}$ genotypes having significantly higher relative concentrations of $\alpha$-LA compared with $\mathrm{BB}$ genotypes $(P=0.0004$ and $P=$ 0.0368 , respectively). Further, $\beta-\mathrm{LG}$ BB genotypes had significantly higher relative concentrations of $\kappa-\mathrm{CN}$ NG compared with AA genotypes in Swedish Mountain cows $(P=0.0434)$.

\section{Milk Compositional Traits in Native Swedish Breeds}

Table 5 shows milk composition in the 2 native Swedish breeds. The cows included in the study were in $\mathrm{d} 20$ to 294 of lactation, with $60 \%$ of the cows being in mid lactation (d 70 to 245). Parity ranged from 1 to 9 , with $72 \%$ of the cows being in parities 1 to 4 . Overall milk composition, detailed protein composition, and technological properties were very similar in the 2 breeds. However, milk $\mathrm{pH}$ was significantly lower in milk from Swedish Red Polled cows than in Swedish Mountain cows $(P=0.015)$. Milk coagulation properties were quite variable within breeds, but only YS displayed significant variability between breeds and was significantly lower in Swedish Red Polled cows compared with Swedish Mountain cows $(P=0.039)$. One milk sample from Swedish Mountain cows was unable to coagulate and thus assigned as $\mathrm{NC}(\mathrm{RCT}>40 \mathrm{~min}$; G'30, $\mathrm{G}^{\prime} 40$, and $\mathrm{YS}=0$ ). Generally, the breeds demonstrated similar protein profiles. Swedish Mountain cows had, however, a significantly higher relative concentration of $\alpha_{\mathrm{S} 1}-\mathrm{CN} 9 \mathrm{P}(P=0.016)$, which was also reflected as a significantly lower $\alpha_{\mathrm{S} 1}-\mathrm{CN}$ PD $(P=0.049)$, meaning that $73 \%$ of total $\alpha_{\mathrm{S1}^{-}} \mathrm{CN}$ was in the $\alpha_{\mathrm{S1}^{-}} \mathrm{CN} 8 \mathrm{P}$ form in Swedish Mountain cows compared with $77 \%$ in Swedish Red Polled cows. No significant variation in micelle size or ionic or total calcium was observed between the 2 native breeds.

\section{Correlation of Milk Traits in Swedish Mountain Cattle}

Figure 2 shows a correlation matrix between traits in milk from Swedish Mountain cows, where 12 of the correlations were significant. As expected, the milk coagulation traits were strongly correlated, with G'30 and YS being positively correlated and both being negatively correlated with RCT. $\kappa$-Casein (the sum of $\kappa-\mathrm{CN}$ G and $\kappa-\mathrm{CN}$ UG) was positively correlated with both $\mathrm{G}^{\prime} 30$ and YS. Further, $\mathrm{k}-\mathrm{CN}$ was negatively correlated with casein micelle size, whereas no significant correlations were found between casein micelle size and $\kappa-\mathrm{CN}$ G $(-0.48)$ or $\kappa$-CN UG $(-0.33)$. Ionic calcium was negatively correlated with $\mathrm{pH}$ and positively correlated with $\mathrm{G}^{\prime} 30$, whereas $\kappa$-CN NG was negatively correlated with protein content and $\beta$-LG. Finally, pH and $\alpha$-LA were positively correlated, whereas $\beta-\mathrm{CN}$ and total calcium were negatively correlated.

\section{Effect of $\beta-k-C N$ Composite Genotypes on Milk Composition in Swedish Mountain Cows}

In Swedish Mountain cows, the reference genotype was $\mathrm{A}^{2} \mathrm{~A}^{2} / \mathrm{AB}$, as only 2 milk samples were assigned $\mathrm{A}^{2} \mathrm{~A}^{2} / \mathrm{AA}$, which was used as reference genotype in Swedish Red. The $\beta-\kappa-C N$ composite genotypes mainly affected $\alpha_{\mathrm{S}_{1}} \mathrm{CN}$ traits (Table 6). Genotypes $\mathrm{A}^{1} \mathrm{~A}^{2} /$ $\mathrm{BB}(P=0.024)$ and $\mathrm{A}^{1} \mathrm{~B} / \mathrm{BB}(P=0.004)$ had lower concentrations of $\alpha_{\mathrm{S}_{1}} \mathrm{CN} 8 \mathrm{P}$ compared with $\mathrm{A}^{2} \mathrm{~A}^{2} / \mathrm{AB}$. This was also reflected in a significantly lower $\alpha_{\mathrm{S1}^{-}} \mathrm{CN}$ $\mathrm{PD}$ for $\mathrm{A}^{1} \mathrm{~B} / \mathrm{BB}$ compared with $\mathrm{A}^{2} \mathrm{~A}^{2} / \mathrm{AB}(P=0.015)$, and a tendency for lower relative concentration of total $\alpha_{\mathrm{S} 1}$ CN $(P=0.094)$. The 5 low-frequency genotypes that were combined into a group showed the same tendency, with lower $\alpha_{\mathrm{S}_{1}} \mathrm{CN} 8 \mathrm{P}(P=0.074)$ and $\alpha_{\mathrm{S}^{-}} \mathrm{CN}$ $\mathrm{PD}(P=0.069)$, compared with $\mathrm{A}^{2} \mathrm{~A}^{2} / \mathrm{AB}$, as well as a significantly higher relative concentration of $\alpha-\mathrm{LA}(P=$ $0.023)$. Genetic variation in $\alpha_{S_{1}}$ CN did not seem to be responsible for the observed differences in relative protein composition among $\beta-\kappa-\mathrm{CN}$ composite genotypes, as only 1 of $4 \mathrm{~A}^{2} \mathrm{~A}^{2} / \mathrm{AB}$ samples was heterozygous for $\alpha_{S 1}-\mathrm{CN}$, and all $\mathrm{A}^{1} \mathrm{~B} / \mathrm{BB}$ and $\mathrm{A}^{1} \mathrm{~A}^{2} / \mathrm{BB}$ samples were $\alpha_{\mathrm{S1}}-\mathrm{CN}$ BB homozygotes.

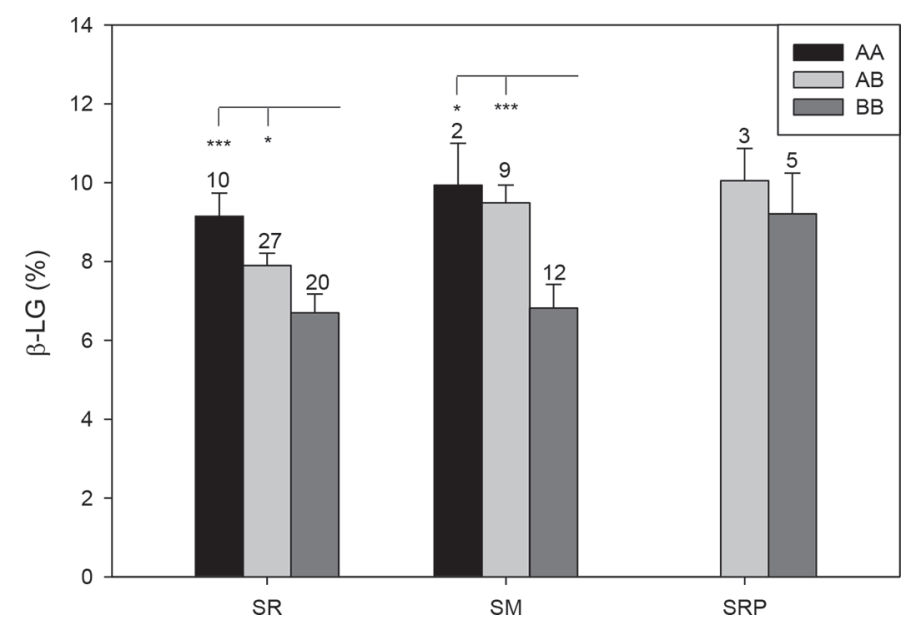

Figure 1. Effect of $\beta-L G$ genotypes on relative concentration of $\beta$-LG. Presented as mean $\pm \mathrm{SE}$ in Swedish Red (SR), Swedish Mountain cattle (SM), and Swedish Red Polled (SRP). Significance values within each breed: ${ }^{*} P<0.05 ;{ }^{* * *} P<0.001$. Numbers above each column refer to the number of samples having a given genotype within each breed. 
Table 5. Descriptive statistics for milk compositional traits in Swedish Mountain $(\mathrm{n}=23)$ and Swedish Red Polled ( $\mathrm{n}=8)$ cows $(\mathrm{mean}$, SD, minimum, and maximum)

\begin{tabular}{|c|c|c|c|c|c|c|c|c|c|}
\hline Trait $^{1}$ & \multicolumn{4}{|c|}{ Swedish Mountain } & \multicolumn{4}{|c|}{ Swedish Red Polled } & Significance \\
\hline Protein $(\mathrm{g} / 100 \mathrm{~g})$ & 3.7 & 0.4 & 2.8 & 4.6 & 3.7 & 0.3 & 3.4 & 4.6 & NS \\
\hline $\mathrm{SCC}\left(\times 10^{3}\right.$ cells $\left./ \mathrm{mL}\right)$ & 82 & 77 & 8 & 272 & 99 & 95 & 6 & 297 & NS \\
\hline $\mathrm{pH}$ & 6.72 & 0.1 & 6.67 & 6.88 & 6.67 & 0.1 & 6.56 & 6.79 & $*$ \\
\hline $\mathrm{G}^{\prime} 40(\mathrm{~Pa})$ & 138.1 & 68.5 & 0 & 263.4 & 129.8 & 75.2 & 42.4 & 292.1 & NS \\
\hline Yield stress $(\mathrm{Pa})$ & 20.7 & 8.1 & 0 & 33.4 & 14.2 & 3.4 & 10.7 & 22.4 & $*$ \\
\hline$\alpha_{\mathrm{S} 1}-\mathrm{CN}(\%)$ & 32.2 & 2.0 & 28.0 & 36.5 & 30.5 & 5.2 & 19.1 & 35.4 & NS \\
\hline$\alpha_{S 1}-C N 8 P(\%)$ & 23.6 & 2.7 & 19.5 & 28.2 & 23.5 & 3.9 & 14.4 & 27.2 & NS \\
\hline$\alpha_{\mathrm{S1}^{1}} \mathrm{CN}$ 9P $(\%)$ & 8.6 & 1.2 & 5.1 & 10.4 & 7.2 & 1.3 & 4.7 & 9.4 & $*$ \\
\hline$\alpha_{S 1}-\mathrm{CN} 8 \mathrm{P} / \alpha_{\mathrm{S1}}-\mathrm{CN}$ & 73.2 & 3.8 & 67.2 & 83.3 & 76.5 & 2.0 & 73.4 & 79.2 & * \\
\hline$\alpha_{S_{2}}-\mathrm{CN}(\%)$ & 7.5 & 1.4 & 5.3 & 11.9 & 7.8 & 2.2 & 5.7 & 12.6 & NS \\
\hline$\alpha-\mathrm{LA}(\%)$ & 4.5 & 0.6 & 3.5 & 5.7 & 4.4 & 1.1 & 3.4 & 7.0 & NS \\
\hline$\beta-\mathrm{LG}(\%)$ & 8.0 & 1.9 & 4.9 & 11.7 & 9.7 & 1.4 & 8.0 & 11.8 & NS \\
\hline Casein micelle size $(\mathrm{nm})$ & 123.5 & 6.6 & 112.8 & 140.0 & 125.4 & 6.0 & 119.3 & 134.5 & NS \\
\hline Total $\mathrm{Ca}(\mathrm{m} M)$ & 25.9 & 4.0 & 20.0 & 33.7 & 25.3 & 3.5 & 20.9 & 30.7 & NS \\
\hline Ionic $\mathrm{Ca}(\mathrm{m} M)$ & 1.9 & 0.4 & 1.2 & 2.6 & 1.8 & 1.1 & 0.9 & 4.4 & NS \\
\hline
\end{tabular}

${ }^{1} \mathrm{RCT}=$ rennet coagulation time; $\mathrm{G}^{\prime} 30$ and $\mathrm{G}^{\prime} 40=$ storage modulus after 30 and 40 min, respectively; $8 \mathrm{P}$ and $9 \mathrm{P}=$ degree of phosphorylation; $\kappa-\mathrm{CN} \mathrm{G}$ and $\kappa-\mathrm{CN} \mathrm{UG}=$ glycosylated and unglycosylated $\kappa-\mathrm{CN}$.

${ }^{2}$ Effect of breed on milk compositional traits: ${ }^{*} P<0.05$.

When using $\mathrm{A}^{2} \mathrm{~A}^{2} / \mathrm{AA}$ as reference genotype $(\mathrm{n}=$ $2)$, it had a lower relative concentration of $\kappa-\mathrm{CN}(P=$ $0.047)$ and a higher relative concentration of $\alpha_{\mathrm{S} 1}-\mathrm{CN} 8 \mathrm{P}$ $(P=0.032)$ compared with $\mathrm{A}^{1} \mathrm{~B} / \mathrm{BB}$ genotypes. The effect of $\beta-\kappa-C N$ composite genotypes was also tested in relation to milk coagulation properties using $\mathrm{A}^{2} \mathrm{~A}^{2} / \mathrm{AB}$ as reference genotype (data not shown). The $\mathrm{A}^{2} \mathrm{~A}^{2} / \mathrm{AA}$ genotype had significantly longer RCT and lower $\mathrm{G}^{\prime} 40$ and YS compared with $\mathrm{A}^{2} \mathrm{~A}^{2} / \mathrm{AB}$. Furthermore, $\mathrm{A}^{1} \mathrm{~A}^{2} /$ $\mathrm{AB}$ showed a tendency of lower YS $(P=0.06)$ compared with $\mathrm{A}^{2} \mathrm{~A}^{2} / \mathrm{AB}$. No effect of composite genotype was observed for ionic and total calcium. Because of the small sample size of Swedish Red Polled, the effect of composite $\beta-\mathrm{k}-\mathrm{CN}$ genotypes on milk compositional traits was not tested.

\section{DISCUSSION}

\section{Frequency Variability of Casein Variants}

The genetic variants identified in the present study have all been found previously in Nordic dairy breeds and most are common (Lien et al., 1999; Poulsen et al., 2013, 2017a). The frequency variation in Swedish Mountain and Swedish Red Polled cows largely confirmed the results of Lien et al. (1999). The current
Swedish Mountain sample population had a lower frequency of $\alpha_{\mathrm{S} 1}-\mathrm{CN} \mathrm{C}(15$ vs. $31 \%$ ) and a higher frequency of $\beta$-CN B (13 vs. 5\%) compared with those found by Lien et al. (1999). In Swedish Red Polled, the presence of $\beta-\mathrm{CN}$ B could not be confirmed, whereas $\beta-\mathrm{CN} \mathrm{A}^{2}$ was found at a much higher frequency and $\beta-\mathrm{CN} \mathrm{A}^{1}$ in a lower frequency than reported by Lien et al. (1999). Further, the relatively high frequency of $\kappa-\mathrm{CN} \mathrm{E}$ was in line with the findings of Lien et al. (1999), whereas the frequency of $\kappa$-CN A was much higher (63 vs. $34 \%$ ) and thus the frequency of $\kappa$-CN B much lower in our sample population of Swedish Red Polled cows (19 vs. 46\%). The reported differences between the study of Lien et al. (1999) and the current study most likely reflect the small sample population rather than changes in population frequencies over time. Further, high genetic relationship between sampled cows in either of the studies could affect the frequency distribution. The sampled native cows represented approximately $2 \%$ of the total population of each native breed. For a more comprehensive study on the variant frequencies, a DNA-based approach is needed because only a small fraction of the native cows are being milked, which reduces sample size in a milk-based identification.

Variant frequencies of the casein genes in the full sample population from Swedish Red cows have previ- 
Table 6. Estimated differences $( \pm \mathrm{SE})$ for relative concentrations of $\alpha_{\mathrm{S1}^{-}} \mathrm{CN} 8 \mathrm{P}, \alpha_{\mathrm{S1}^{-}} \mathrm{CN}, \alpha_{\mathrm{S}^{-}} \mathrm{CN}$ phosphorylation degree $\left(\alpha_{\mathrm{S} 1}-\mathrm{CN} \mathrm{PD}\right)$, and $\alpha$-LA comparing $\beta$ - $\kappa$-CN composite genotypes with the common composite genotype, $\mathrm{A}^{2} \mathrm{~A}^{2} / \mathrm{AB}$, in Swedish Mountain cows

\begin{tabular}{|c|c|c|c|c|}
\hline$\beta-\kappa-C N$ genotype ${ }^{1}$ & $\alpha_{\mathrm{S} 1}-\mathrm{CN} 8 \mathrm{P}(\%)$ & $\alpha_{\mathrm{S} 1}-\mathrm{CN}(\%)$ & $\alpha_{\mathrm{S}_{1}-} \mathrm{CN}$ PD $(\%)$ & $\alpha-\mathrm{LA}(\%)$ \\
\hline $\begin{array}{l}\mathrm{A}^{2} \mathrm{~A}^{2} / \mathrm{AB}(\mathrm{n}=4) \\
\mathrm{A}^{2} \mathrm{~A}^{2} / \mathrm{AA}(\mathrm{n}=2) \\
\mathrm{A}^{1} \mathrm{~A}^{2} / \mathrm{AB}(\mathrm{n}=3) \\
\mathrm{A}^{1} \mathrm{~A}^{2} / \mathrm{BB}(\mathrm{n}=3) \\
\mathrm{A}^{2} \mathrm{~A}^{2} / \mathrm{BB}(\mathrm{n}=3) \\
\mathrm{A}^{1} \mathrm{~B} / \mathrm{BB}(\mathrm{n}=3) \\
\text { Other }^{2}(\mathrm{n}=5) \\
\text { Mean }\end{array}$ & $\begin{aligned} & 0 \\
&-0.66 \pm 1.42 \\
&-1.35 \pm 1.25 \\
&-3.12 \pm 1.25^{*} \\
&-0.11 \pm 1.25 \\
&-4.16 \pm 1.25^{* *} \\
&-2.10 \pm 1.10 \dagger \\
& 25.27 \pm 0.82\end{aligned}$ & $\begin{aligned} 0 & \\
0.79 & \pm 1.64 \\
-0.64 & \pm 1.45 \\
-2.33 & \pm 1.45 \\
0.26 & \pm 1.45 \\
-2.58 & \pm 1.45 \dagger \\
-0.88 & \pm 1.27 \\
33.01 & \pm 0.95\end{aligned}$ & $\begin{array}{c}0 \\
-3.77 \pm 3.03 \\
-2.73 \pm 2.67 \\
-4.30 \pm 2.67 \\
-0.27 \pm 2.67 \\
-7.26 \pm 2.67^{*} \\
-4.57 \pm 2.35 \dagger \\
76.62 \pm 1.75\end{array}$ & $\begin{aligned} 0 \\
0.13 \pm 0.45 \\
0.31 \pm 0.40 \\
0.81 \pm 0.40 \dagger \\
0.54 \pm 0.40 \\
-0.01 \pm 0.40 \\
0.88 \pm 0.35^{*} \\
4.10 \pm 0.26\end{aligned}$ \\
\hline
\end{tabular}

${ }^{1}$ All cows were homozygous for $\alpha_{\mathrm{S}_{1}} \mathrm{CN}$ BB except $2 \alpha_{\mathrm{S}^{-}} \mathrm{CN}$ BC samples (one $\mathrm{A}^{2} \mathrm{~A}^{2} / \mathrm{AB}$ and one $\mathrm{A}^{2} \mathrm{~A}^{2} / \mathrm{BB}$ ) and $1 \alpha_{\mathrm{S}^{-}} \mathrm{CN}$ CC sample $\left(\mathrm{A}^{2} \mathrm{~A}^{2} / \mathrm{BB}\right)$.

${ }^{2}$ Other refers to composite $\beta$ - $\kappa$-CN genotypes only found in 1 or 2 cows in Swedish Mountain.

$\dagger P<0.1,{ }^{*} P<0.05,{ }^{*} * P<0.01$.

ously been estimated using a DNA-based genotyping protocol (Poulsen et al., 2013). Variant F was not targeted in the DNA-based approach, but use of LC/ ESI-MS provided additional characterization of $\beta-\mathrm{CN}$ F, which was identified in one Swedish Red NC milk sample as a heterozygote. In native Danish breeds, this variant was also found to be associated with $\mathrm{NC}$ and

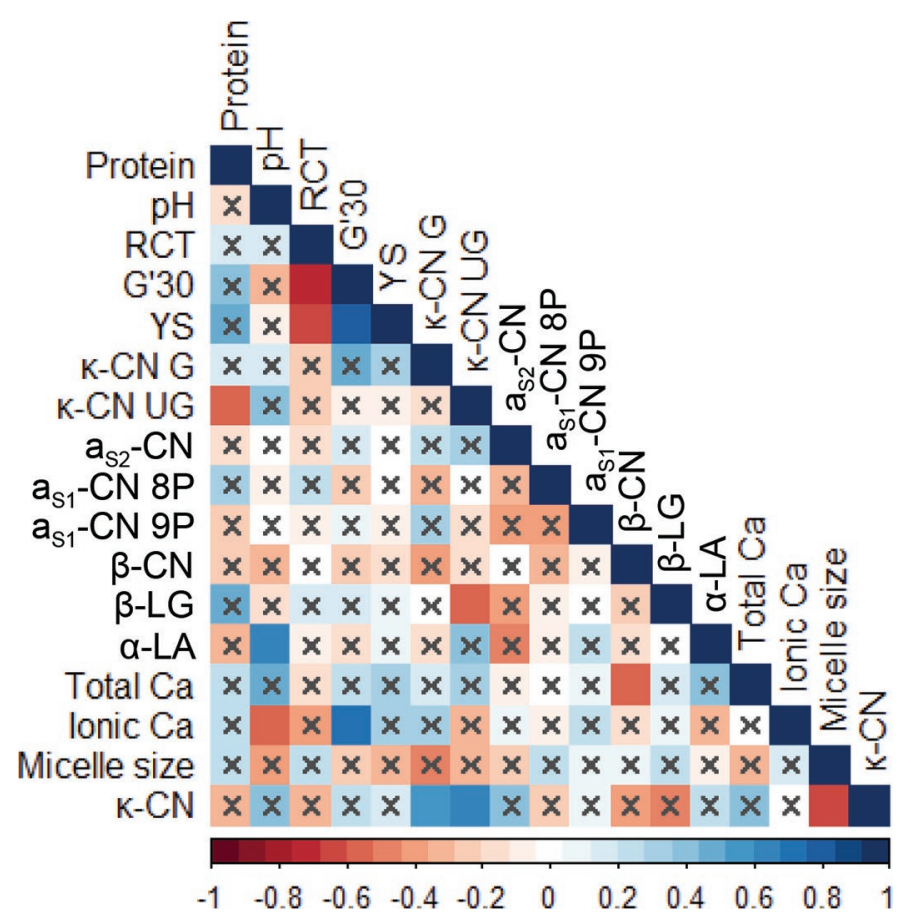

Figure 2. Pearson correlation heatmap between milk composition parameters, coagulation properties, and relative protein concentration in milk from Swedish Mountain cows $(\mathrm{n}=23)$. Correlations marked with $\times$ were not significant based on $F$-test $(P>0.01)$. RCT $=$ rennet coagulation time; $\mathrm{G}^{\prime} 30=$ storage modulus after $30 \mathrm{~min}$; YS $=$ yield stress; $\kappa-\mathrm{CN} \mathrm{G}$ and $\kappa-\mathrm{CN} \mathrm{UG}=$ glycosylated and unglycosylated $\kappa-\mathrm{CN}$, respectively. Color version available online. poorly coagulating milk (Poulsen et al., 2017a). The higher frequencies of $\beta-\mathrm{CN} \mathrm{A}{ }^{2}, \kappa-C N A$, and $\kappa-C N E$ in the NC milk samples were in line with the reported genotype frequencies for all Swedish Red NC milk samples (Poulsen et al., 2013). In contrast to the DNA-based approach, we found a low frequency of $\beta-C N$ B in the WC group. It is not clear what drives the discrepancy between the methods. However, as $\beta-\mathrm{CN}$ B has previously been associated with good coagulation properties and the variant is found only in WC (Poulsen et al., 2013), it strengthens the LC/ESI-MS based findings.

\section{Protein Composition Between Coagulation Groups in Swedish Red}

Interestingly, the main difference in protein composition between $\mathrm{NC}$ and $\mathrm{WC}$ samples was related to the relative concentrations of $\alpha_{\mathrm{S}_{1}-} \mathrm{CN}, \alpha_{\mathrm{S}^{2}} \mathrm{CN}$, and $\alpha-\mathrm{LA}$ rather than variation in $\kappa-\mathrm{CN}$. A negative influence of $\alpha_{\mathrm{S}_{2}} \mathrm{CN}$ on milk coagulation properties was found by Joudo et al. (2008), where the fraction of $\alpha_{\mathrm{S2}_{2}} \mathrm{CN}$ in total CN was significantly higher in $\mathrm{NC}$ milk compared with coagulating milk samples. Variation in posttranslational modifications of $\alpha_{\mathrm{S} 1}-\mathrm{CN}$ and $\alpha_{\mathrm{S} 2}-\mathrm{CN}$ also play a role in milk coagulation properties, with a higher fraction of $\alpha_{S_{1}}-\mathrm{CN} 8 \mathrm{P}$ and $\alpha_{\mathrm{S}^{-}} \mathrm{CN} 11 \mathrm{P}$ being related to good coagulation properties in Danish Holstein (Frederiksen et al., 2011; Jensen et al., 2012). This was not confirmed in the current study. In Danish Jersey cows, a higher relative fraction of $\alpha$-LA was associated with $\mathrm{NC}$ and poorly coagulating milk (Poulsen et al., 2016). Increasing the relative concentration of $\alpha$-LA may affect the casein-to-whey ratio, as the relative concentrations of $\alpha$-LA and $\beta$-LG were positively correlated; thus, increasing relative contents of the whey proteins would lower the casein-to-whey ratio, which may in turn affect milk coagulation properties negatively. 
A positive influence of increased relative concentrations of $\kappa$-CN on milk coagulation properties is well documented (Wedholm et al., 2006; Jensen et al., 2012). This could be a consequence of the underlying $\kappa-\mathrm{CN}$ genotypes, where $\kappa-\mathrm{CN} \mathrm{B}$ is related to higher relative content of $\kappa-\mathrm{CN}$ and a higher GD (Poulsen et al., 2016). Here, a higher frequency of $\kappa-\mathrm{CN}$ variant $\mathrm{B}$ was found in the WC group, but this was not reflected in significantly higher content of $\kappa-\mathrm{CN}$ in $\mathrm{WC}$ milk. Gustavsson et al. (2014b) found that protein content, ionic calcium, and casein micelle size were the most important factors explaining milk coagulation in Swedish Red, whereas NC milk in Swedish Red was mainly related to lower ionic and total calcium levels as well as lower relative content of $\beta$-LG.

\section{Effect of $\beta-\kappa-C N$ Composite Genotypes in Swedish Red}

A large screening study of Swedish Red has already documented the effect of $\beta-\kappa-\mathrm{CN}$ composite genotypes on protein variation (Gustavsson et al., 2014c). Compared with the capillary zone electrophoresis method used by Gustavsson et al. (2014c), the LC/ESI-MS method used here gave an improved resolution of $\kappa-\mathrm{CN}$, allowing $\kappa-\mathrm{CN} \mathrm{G}$ and $\kappa-\mathrm{CN} \mathrm{UG}$ to be identified as separate traits. Gustavsson et al. (2014c) reported highly significant effects of all composite genotypes on $\kappa$-CN NG ( $\kappa-\mathrm{CN} 1 \mathrm{P})$ and adjusted $\kappa$-CN contents (included share of glycosylated $\kappa-\mathrm{CN}$ but adjusted due to co-elution with some $\beta$-CN variants) compared with the reference genotype $\left(\mathrm{A}^{2} \mathrm{~A}^{2} / \mathrm{AA}\right)$. The present study confirmed the effect of composite genotypes on total $\kappa-\mathrm{CN}$ level, and most composite genotypes had an increased level of $\kappa-\mathrm{CN} \mathrm{G}$, but unchanged levels of $\kappa-\mathrm{CN}$ UG compared with the reference genotype.

The influence of the composite genotypes on $\alpha_{\mathrm{S}_{1}} \mathrm{CN}$ seems to be related to the relative content of $\alpha_{\mathrm{S}_{1}} \mathrm{CN} 8 \mathrm{P}$ rather than $\alpha_{\mathrm{S}^{1}} \mathrm{CN} 9 \mathrm{P}$, which contrasts the result found by Gustavsson et al. (2014c), where the effect was most pronounced for $\alpha_{\mathrm{S}_{1}} \mathrm{CN} 9 \mathrm{P}$ contents. For both methods, $\alpha_{\mathrm{S}_{1}-\mathrm{CN}} 8 \mathrm{P}$ and $\alpha_{\mathrm{S} 1}-\mathrm{CN} 9 \mathrm{P}$ are not fully separated and this difference may affect peak integration. Compared with the study by Gustavsson et al. (2014c), we could not confirm the significant effect of composite $\beta-\kappa-C N$ genotypes on $\beta-L G$ in this study.

In Poulsen et al. (2013), composite genotypes were related to milk coagulation properties measured by free oscillation. Apart from the $\mathrm{A}^{1} \mathrm{~A}^{2} / \mathrm{AE}$ and $\mathrm{A}^{2} \mathrm{~A}^{2} / \mathrm{AB}$ genotypes, the other composite genotypes had significantly higher curd firming rate compared with $\mathrm{A}^{2} \mathrm{~A}^{2} /$ $\mathrm{AA}$, whereas only the $\mathrm{A}^{1} \mathrm{~A}^{1} / \mathrm{AE}$ genotype had significantly shorter RCT. These results can be reflected in the frequencies found for the 2 coagulation groups: $\mathrm{A}^{1} \mathrm{~A}^{2} / \mathrm{AE}$ and $\mathrm{A}^{2} \mathrm{~A}^{2} / \mathrm{AB}$ had higher frequencies in cows producing $\mathrm{NC}$ milk, whereas $\mathrm{A}^{1} \mathrm{~A}^{1} / \mathrm{AE}$ was only found in the WC group.

\section{Effect of $\beta-L G$ Variants}

The higher relative concentrations of $\beta$-LG for AA and $\mathrm{AB} \beta-\mathrm{LG}$ genotypes in all breeds are in agreement with previous results (Hallén et al., 2008; Bonfatti et al., 2010a). Jensen et al. (2012) found that the frequency of $\beta$-LG A was lower in a group of WC Danish Holstein and Jersey milk samples compared with the frequency in groups of poorly coagulating and NC milk samples. In Swedish Red, we could not confirm this, and the frequency of the $\mathrm{B}$ variant of $\beta$-LG was higher in the NC group than in the WC group. Thus, our results suggest that even though there is a genetic influence of $\beta-\mathrm{LG}$ variants on the relative concentration of $\beta-\mathrm{LG}$, this is not reflected in the milk coagulation groups. $\beta$-Lactoglobulin genotypes have also been shown to affect acid-induced milk coagulation properties, which is important for fermented products; however, the results are somewhat contradictory for $\beta$-LG A and B (Allmere et al., 1998; Hallén et al., 2009; Glantz et al., 2015).

\section{Milk Compositional and Processing Traits of Swedish Mountain and Swedish Red Polled}

Swedish Mountain cows had a significantly higher YS compared with Swedish Red Polled. Yield stress is a measure of large deformation properties and thus reflects when cheese is cut after the coagulation process. The milk coagulation properties of both breeds were superior to those reported in Swedish Red using the same methodology and experimental conditions (Gustavsson et al., 2014a). A major explanation for this is the high frequency of NC milk in Swedish Red (16\%, Poulsen et al., 2013), but even when these NC samples are excluded from the data analysis, milk from the native breeds still displays shorter RCT and higher G'40, although mean YS was higher only in milk from Swedish Mountain cows. Because the protein concentration was similar across all samples, factors other than total protein level must explain the impaired milk coagulation properties of Swedish Red milk. The relative protein compositions in milk from Swedish Red cows and native breeds were not analyzed at the same time. Thus, as no internal standard was included, variation due to column drift or change of column could lead to differences between these 2 data sets. Despite this uncertainty, the combined Swedish Red samples presented here had significantly lower relative concen- 
trations of $\kappa-\mathrm{CN}$ and $\alpha$-LA compared with the native breeds, but significantly higher relative concentrations of $\beta-\mathrm{CN}$ (data not shown). Variation in $\beta-\mathrm{CN}$ and $\kappa-\mathrm{CN}$ does not seem to be responsible for NC milk within Swedish Red, but the changed ratio between these proteins in Swedish Red in general may be one of the underlying drivers behind the overall poorer coagulation properties of milk from Swedish Red and could manifest in differences in casein micelle size. When the protein composition in milk from Swedish Red cows was compared with that from Danish Holstein and Danish Jersey based on results generated by capillary zone electrophoresis, Swedish Red had a higher relative concentration of $\beta-\mathrm{CN}$ and a lower relative concentration of $\kappa-\mathrm{CN}$ than Danish Jersey and Danish Holstein, but variations in other proteins were also significant. Several factors could thus explain variations in milk coagulation properties between breeds (Poulsen et al., 2013), and the underlying cause for the high prevalence of NC milk in Swedish Red is still not clear.

Apart from protein composition, another important factor for milk processing properties, and especially for rennet coagulation properties, is casein micelle size and milk calcium distribution. Smaller casein micelles have been associated with improved milk coagulation properties (Glantz et al., 2010; Poulsen et al., 2017b). Compared with results reported in milk from Swedish Red (Gustavsson et al., 2014b), average casein micelle size in the native breeds was smaller. Lower contents of ionic calcium and total calcium have been associated with NC milk in Swedish Red (Gustavsson et al., 2014b). In a set of the samples from Swedish Red, mean ionic calcium concentration was $1.94 \mathrm{mM}$ (Gustavsson et al., 2014b), which is similar to that in milk from Swedish Mountain and Swedish Red Polled cows in the current study. Total calcium content of the native breeds found in the present study was lower than reported previously in Swedish Red (Gustavsson et al., 2014b) and in Danish Holstein and Danish Jersey (Jensen et al., 2012). However, if milk from Swedish Mountain and Swedish Red Polled cows has lower total and ionic calcium levels, this could negatively affect the milk coagulation properties. The fact that the native breeds have improved coagulation properties compared with Swedish Red suggests that the potential negative effects of lower total and ionic calcium must be circumvented by other factors; for example, higher $\kappa$-CN content and lower $\beta$-CN content.

\section{Effect of $\beta-K-C N$ Composite Genotypes in Swedish Mountain Cattle}

In milk from Swedish Mountain cows, the most common $\beta-\kappa-C N$ composite genotypes was related to higher relative content of $\alpha_{\mathrm{S}_{1}}-\mathrm{CN} 8 \mathrm{P}$ and somewhat lower content of $\alpha$-LA. As another $\beta-\kappa-\mathrm{CN}$ genotype was used as reference genotype in Swedish Red cows in the present study, the results were not directly comparable but clearly indicate that genetic variation in the casein genes also affects the detailed protein composition in the native breeds. The genotype of the NC milk sample from Swedish Mountain cattle was $\mathrm{A}^{2} \mathrm{~A}^{2} / \mathrm{AA}$. This genotype had a very high frequency in $\mathrm{NC}$ milk from Swedish Red cows, which may suggests similar underlying genetic influence for NC milk across breeds.

\section{Correlation of Milk Traits in Swedish Mountain Cattle}

The very strong positive correlation between YS and $\mathrm{G}^{\prime} 30(\mathrm{r}=0.79)$ confirmed earlier findings based on milk from Swedish Red cows ( $\mathrm{r}=0.83)$, and a stronger association between protein and YS than between protein and $\mathrm{G}^{\prime} 30$ was also found here, even though these correlations were not significant (Gustavsson et al., 2014a). The observed strong correlation between ionic calcium and $G^{\prime} 30$ is in agreement with Tsioulpas et al. (2007), where a higher content of ionic calcium had a positive influence on gel firmness. However, as lower $\mathrm{pH}$ also affected gel firmness positively, it was not clear whether the observed effects were due to the effect of ionic calcium, $\mathrm{pH}$, or a combination. We also found an inverse correlation between ionic calcium and $\mathrm{pH}$ in the fresh milk, but fresh milk $\mathrm{pH}$ was not significantly associated with milk coagulation traits. Higher levels of ionic calcium will lower the surface charge of para-casein and improve cross-linking during aggregation (Dalgleish, 1983; Hyslop, 2003). It is surprising that no significant correlations were found between milk coagulation properties and the relative protein profile, especially as a strong inverse correlation $(\mathrm{r}=-0.63)$ between the relative concentration of $\kappa-\mathrm{CN}$ and casein micelle size was found, as also documented earlier (Bijl et al., 2014; Poulsen et al., 2017b). It is not clear what drives the inverse correlations between $\kappa$-CN UG and protein content or relative concentration of $\beta$-LG. Further, to our knowledge, the inverse correlation between total calcium and $\beta-\mathrm{CN}$ has not been documented before.

\section{CONCLUSIONS}

In Swedish Red cows, lower protein content, a higher fraction of $\alpha_{\mathrm{S}^{2}} \mathrm{CN}$, and a lower fraction of $\alpha_{\mathrm{S}^{1}} \mathrm{CN} 9 \mathrm{P}$ were related to NC milk. The effect of $\beta-\kappa-\mathrm{CN}$ composite genotypes in Swedish Red significantly affected the relative concentration of $\kappa-\mathrm{CN}$ (mainly $\kappa-\mathrm{CN} \mathrm{G}$ ), $\alpha_{\mathrm{S1}^{-}}$ $\mathrm{CN}$ (mainly $\left.\alpha_{\mathrm{S}^{-}} \mathrm{CN} 8 \mathrm{P}\right), \alpha_{\mathrm{S}^{-}} \mathrm{CN}$, and $\beta-\mathrm{CN}$. The native breeds displayed superior coagulation properties and a low frequency of NC milk compared with Swedish Red, 
suggesting that their milk is more suitable for cheese production. This may be due to higher relative content of $\kappa-\mathrm{CN}$ in the native breeds than in milk from Swedish Red. The study confirmed a very high frequency of $\kappa-\mathrm{CN}$ variant B in Swedish Mountain cows. Furthermore, level of ionic calcium was found to be important for gel firmness in milk from Swedish Mountain cows.

\section{ACKNOWLEDGMENTS}

The authors thank The Royal Swedish Academy of Agriculture and Forestry (Stockholm, Sweden), the Swedish Farmer's Foundation for Agricultural Research (SLF; Stockholm, Sweden), and Aarhus University (Aarhus, Denmark) for financial support. The farmers providing milk for the projects are also thanked for the collaboration. The authors thank Frida Gustavsson at the Department of Food Technology, Engineering and Nutrition, Lund University, Sweden, for her help with the experimental work.

\section{REFERENCES}

Allmere, T., A. Andren, M. Lindersson, and L. Björck. 1998. Studies on rheological properties of stirred milk gels made from milk with defined genetic variants of $\kappa$-casein and $\beta$-lactoglobulin. Int. Dairy J. 8:899-905.

Bijl, E., R. de Vries, H. van Valenberg, T. Huppertz, and T. van Hooijdonka. 2014. Factors influencing casein micelle size in milk of individual cows: Genetic variants and glycosylation of $\kappa$-casein. Int. Dairy J. 34:135-141.

Bobe, G., D. C. Beitz, A. E. Freeman, and G. L. Lindberg. 1998. Separation and quantification of bovine milk proteins by reversed-phase high-performance liquid chromatography. J. Agric. Food Chem. 46:458-463.

Bonfatti, V., G. Di Martino, A. Cecchinato, L. Degano, and P. Carnier. 2010a. Effects of $\beta$ - $\kappa$-casein (CSN2-CSN3) haplotypes, $\beta$-lactoglobulin $(B L G)$ genotypes, and detailed protein composition on coagulation properties of individual milk of Simmental cows. J. Dairy Sci. 93:3809-3817.

Bonfatti, V., G. Di Martino, A. Cecchinato, D. Vicario, and P. Carnier. 2010b. Effects of $\beta$ - $\kappa$-casein (CSN2-CSN3) haplotypes and $\beta$-lactoglobulin $(B L G)$ genotypes on milk production traits and detailed protein composition of individual milk of Simmental cows. J. Dairy Sci. 93:3797-3808.

Bonfatti, V., L. Grigoletto, A. Cecchinato, L. Gallo, and P. Carnier. 2008. Validation of a new reversed-phase high-performance liquid chromatography method for separation and quantification of bovine milk protein genetic variants. J. Chromatogr. A 1195:101-106.

Dalgleish, D. G. 1983. Coagulation of renneted bovine casein micelles: Dependence on temperature, calcium ion concentration and ionic strength. J. Dairy Res. 50:331-340.

Frederiksen, P. D., K. K. Andersen, M. Hammershoj, H. D. Poulsen, J. Sorensen, M. Bakman, K. B. Qvist, and L. B. Larsen. 2011. Composition and effect of blending on noncoagulating, poorly coagulating and well-coagulating bovine milk from individual Danish Holstein cows. J. Dairy Sci. 94:4787-4799.

Glantz, M., T. G. Devold, G. E. Vegarud, H. Lindmark Månsson, H. Stålhammar, and M. Paulsson. 2010. Importance of casein micelle size and milk composition for milk gelation. J. Dairy Sci. 93:1444-1451.

Glantz, M., F. Gustavsson, H. P. Bertelsen, H. Stålhammar, H. L. Månsson, M. Paulsson, C. Bendixen, and V. R. Gregersen. 2015.
Bovine chromosomal regions affecting rheological traits in acidinduced skim milk gels. J. Dairy Sci. 98:1273-1285.

Glantz, M., H. L. Månsson, H. Stălhammar, and M. Paulsson. 2011. Effect of polymorphisms in the leptin, leptin receptor, and acylcoenzyme A:diacylglycerol acyltransferase 1 (DGAT1) genes and genetic polymorphism of milk proteins on cheese characteristics. J. Dairy Sci. 94:3295-3304.

Gregersen, V. R., F. Gustavsson, M. Glantz, O. Christensen, H. Stålhammar, A. Andrén, H. L. Månsson, N. A. Poulsen, L. B. Larsen, M. Paulsson, and C. Bendixen. 2015. Bovine chromosomal regions affecting rheological traits in rennet-induced skim milk gels. J. Dairy Sci. 98:1261-1272.

Gustavsson, F., A. J. Buitenhuis, M. Johansson, H. P. Bertelsen, M. Glantz, N. A. Poulsen, H. Lindmark-Månsson, H. Stålhammar, L. B. Larsen, C. Bendixen, M. Paulsson, and A. Andrén. 2014c. Effects of breed and casein genetic variants on protein profile in milk from Swedish Red, Danish Holstein, and Danish Jersey cows. J. Dairy Sci. 97:3866-3877.

Gustavsson, F., M. Glantz, A. J. Buitenhuis, H. Lindmark-Månsson, H. Stålhammar, A. Andrén, and M. Paulsson. 2014b. Factors influencing chymosin-induced gelation of milk from individual dairy cows: Major effects of casein micelle size and calcium. Int. Dairy J. 39:201-208.

Gustavsson, F., M. Glantz, N. A. Poulsen, L. Wadsö, H. Stålhammar, A. Andrén, H. L. Månsson, L. B. Larsen, M. Paulsson, and W. F. Fikse. 2014a. Genetic parameters for rennet- and acid-induced coagulation properties in milk from Swedish Red dairy cows. J. Dairy Sci. 97:5219-5229.

Hallén, E., T. Allmere, A. Lundén, and A. Andrén. 2009. Effect of genetic polymorphism of milk proteins on rheology of acid-induced milk gels. Int. Dairy J. 19:399-404.

Hallén, E., T. Allmere, J. Näslund, A. Andrén, and A. Lundén. 2007. Effect of genetic polymorphism of milk proteins on rheology of chymosin-induced milk gels. Int. Dairy J. 17:791-799.

Hallén, E., A. Wedholm, A. Andrén, and A. Lundén. 2008. Effect of $\beta$-casein, $\kappa$-casein and $\beta$-lactoglobulin genotypes on concentration of milk protein variants. J. Anim. Breed. Genet. 125:119-129.

Heck, J. M. L., A. Schennink, H. J. F. van Valenberg, H. Bovenhuis, M. H. P. W. Visker, J. A. M. Arendonk, and A. C. M. van Hooijdonk. 2009. Effects of milk protein variants on the protein composition of bovine milk. J. Dairy Sci. 92:1192-1202.

Hyslop, D. B. 2003. Enzymatic coagulation of milk. Pages 839-878 in Advanced Dairy Chemistry: Proteins. Vol. 1. P. F. Fox and P. L. H. McSweeney, ed. Kluwer Academic/Plenum, New York, NY.

Ikonen, T., K. Ahlfors, R. Kempe, M. Ojala, and O. Ruottinen. 1999 Genetic parameters for the milk coagulation properties and prevalence of noncoagulating milk in Finnish dairy cows. J. Dairy Sci. $82: 205-214$

Jensen, H. B., N. A. Poulsen, K. K. Andersen, M. Hammershøj, H. D. Poulsen, and L. B. Larsen. 2012. Distinct composition of bovine milk from Jersey and Holstein-Friesian cows with non, poor or good coagulation properties as reflected in protein genetic variants and isoforms. J. Dairy Sci. 95:6905-6917.

Jõudo, I., M. Henno, T. Kaart, T. Pussa, and O. Kart. 2008. The effect of milk protein contents on the rennet coagulation properties of milk from individual dairy cows. Int. Dairy J. 18:964-967.

Kantanen, J., I. Olsaker, L.-E. Holm, S. Lien, J. Vilkki, K. Brusgaard, E. Eythorsdottir, B. Danell, and S. Adalsteinsson. 2000. Genetic diversity and population structure of 20 North European cattle breeds. J. Hered. 91:446-457.

Li, M.-H., and J. Kantanen. 2010. Genetic structure of Eurasian cattle (Bos taurus) based on microsatellites: Clarification for their breed classification. Anim. Genet. 41:150-158.

Lien, S., J. Kantanen, I. Olsaker, L.-E. Holm, E. Eythorsdottir, K. Sandberg, B. Dalsgard, and S. Adalsteinsson. 1999. Comparison of milk protein allele frequencies in Nordic cattle breeds. Anim. Genet. 30:85-91.

Poulsen, N. A., H. P. Bertelsen, H. B. Jensen, F. Gustavsson, M. Glantz, H. Lindmark Månsson, A. Andrén, M. Paulsson, C. Bendixen, A. J. Buitenhuis, and L. B. Larsen. 2013. The occurrence of non-coagulating milk and the association of bovine milk coagula- 
tion properties with genetic variants of the caseins in 3 Scandinavian dairy breeds. J. Dairy Sci. 96:4830-4842.

Poulsen, N. A., V. R. Gregersen, G. M. Maciel, L. B. Madsen, B. Buitenhuis, M. S. Hansen, C. Bendixen, and L. B. Larsen. 2017b. Novel genetic markers associated to CSN3 strongly affect rennetinduced milk coagulation. Int. Dairy J. 71:122-130.

Poulsen, N. A., H. B. Jensen, and L. B. Larsen. 2016. Factors influencing degree of glycosylation and phosphorylation of caseins in individual cow milk samples. J. Dairy Sci. 99:3325-3333.

Poulsen, N. A., A. K. Rosengaard, B. D. Szekeres, V. R. Gregersen, H. B. Jensen, and L. B. Larsen. 2017a. Protein heterogeneity of bovine $\beta$-casein in Danish dairy breeds and association of rare $\beta$-casein F with milk coagulation properties. Acta Agric. Scand. A Anim. Sci. 66:190-198.

Tapio, I., S. Värv, J. Bennewitz, J. Maleviviute, E. Fimland, Z. Grislis, T. H. E. Meuwissen, I. Miceikiene, I. Olsaker, H. Viinalass, J. Vilkki, and J. Kantanen. 2006. Prioritization for conservation of
Northern European cattle breeds based on analysis of microsatellite data. Conserv. Biol. 20:1768-1779.

Tsioulpas, A., M. J. Lewis, and A. S. Grandison. 2007. Effect of minerals on casein micelle stability of cows' milk. J. Dairy Res. $74: 167-173$

Tyrisevä, A. M., K. Elo, A. Kuusipuro, V. Vilva, I. Janönen, H. Karjalainen, T. Ikonen, and M. Ojala. 2008. Chromosomal regions underlying noncoagulation of milk in Finnish Ayrshire cows. Genetics 180:1211-1220.

Tyrisevä, A. M., T. Vahlsten, O. Routtinen, and M. Ojala. 2004. Noncoagulation of milk in Finnish Ayrshire and Holstein-Friesian cows and effect of herds on milk coagulation ability. J. Dairy Sci. 87:3958-3966.

Wedholm, A., L. B. Larsen, H. Lindmark-Månsson, A. H. Karlsson, and A. Andrén. 2006. Effect of protein composition on the cheesemaking properties of milk from individual dairy cows. J. Dairy Sci. 89:3296-3305. 